\title{
ASPECTOS POLÊMICOS DA LEI 11.705/2008 (LEI SECA) - ANÁLISE NO ÂMIBITO DOS PRINCIÍPIOS CONSTITUCIONAIS DO DIREITO PENAL E DO DIREITO PROCESSUAL PENAL
}

\section{Emerson Castelo Branco}

Defensor público. Mestre em Direito Público pela Universidade Federal do Ceará. Professor de Direito Penal na FA7 e de Processo Penal na Universidade de Fortaleza. emersoncbm@yahoo.com.br

A Lei N. ${ }^{\circ}$ 11.705, de 19 de junho de 2008, denominada Lei Seca, com o caráter rigoroso das suas disposições, ao menos inicialmente, vem obtendo nítida eficácia no combate à criminalidade na direção do veículo automotor. Essa constatação pode ser aferida pelas últimas estatísticas acerca de acidentes automobilísticos com resultado morte, demonstrando a diminuição destes.

E, de fato, faziam-se necessárias disposições mais rigorosas para coibir a violência no trânsito. Afinal, o Brasil enfrenta a trágica realidade de 35 mil mortes e 400 mil feridos em acidentes, provocados dolosa ou culposamente por motoristas que desenvolvem a denominada "condução homicida".

Se por um lado pode-se argumentar que as novas disposições seguem na contramão dos princípios modernos do Direito Penal, como a intervenção mínima; por outro, os argumentos a favor das campanhas de educação no trânsito precisam ser colocados em cheque, porque não vinham surtindo o efeito pretendido.

Dentro dessa realidade, o aspecto inibitório da nova Lei merece elogios. Há muito se reivindicava tolerância zero para um dos trânsitos de veículos mais violentos do mundo. Contudo, os elogios param por aí. O legislador pensou nos fins, e não nos meios. A Lei Seca, em seu âmago, está eivada de inconstitucionalidades alarmantes.

Primeiro, porque lesa o princípio constitucional da razoabilidade. A quantidade mínima de álcool no sangue merece ser desconsiderada, por ser um irrelevante penal. 
Segundo, porque lesa o princípio constitucional da culpabilidade, consagrando este, no Direito Penal, a responsabilidade subjetiva. Não se pode estabelecer como crime a mera conduta de dirigir, após fazer a ingestão de bebida alcoólica. Se o motorista conduzia o veículo com absoluta normalidade e segurança, como se lhe imputar a prática de um delito? Isso seria trazer a teratológica responsabilidade objetiva dos calabouços da Idade Média.

Terceiro, lesão ao princípio da ofensividade. Não haverá crime sem ofensa ao bem jurídico protegido. A ausência de lesão ao bem jurídico torna o fato atípico. É inconcebível, em pleno Estado Democrático de Direito, prender em flagrante o sujeito todas as vezes que esteja dirigindo com seis decigramas ou mais de álcool por litro de sangue, sem aferir se este desenvolvia uma condução anormal; ou, ao menos, se o seu estado comprometia a segurança no trânsito (bem tutelado na norma penal).

Quarto, a garantia da não auto-incriminação, decorrente do princípiovetor da dignidade da pessoa humana. A pessoa não pode ser obrigada a ceder seu corpo para a elaboração de exames de bafômetro e de sangue. $\mathrm{O}$ ônus da prova cabe ao Estado.

Diante do quadro analisado, incumbe aos juízes a responsabilidade de interpretar as novas disposições sob a perspectiva dos princípios constitucionais do Estado Democrático de Direito, procedendo às devidas correções. 